\title{
The Effect of Ginger (Zingiber Officinale Roscoe) Extract to the Number of Neutrophil Cell in Incision Wound of White Rats (Rattus Norvegicus)
}

\author{
Idola Perdana Sulistyoning Suharto *, Kun Ika Nur Rahayu and Arif Nurma Etika \\ Faculty of Science, Kadiri University, Indonesia \\ Jl. Selomangleng No. 1, Pojok, Mojoroto, Hutan, Mojoroto, Kota Kediri, Jawa Timur, 64115 \\ *Corresponding author: idolaperdana@gmail.com
}

\begin{abstract}
Background: Wounds is a discontinuity of tissue. Incision wounds is a wound that made by clean pieces use sharp tools. Inflamation phasein wound healing marked by the activity of neutrophils cells. Nowadays, demand of herbal plants increase, it were used as an alternative therapy. One of the herbal plants in Indonesian is ginger (Zingiber officinale roscoe). This plant contain oleoresin, gingerol \& shogaol that have a role as anti-inflammation. Objective: The study purpose was to analysis the effect of ginger extract to the number of neutrophil cell in incision wound of white rats. Method: Design was randomized posted-only control group design. 30 male rats grouped on control and treatment group. Control group divided into three groups and also treatment group divided into three groups. Control group just given CMC $1 \%$ peroral without ginger extract, the treatment group given ginger extract 1 $\mathrm{g} / \mathrm{kg}$ body weight. The data was analyzed by Kruskall Wallis test and then continued to Mann-Whitney $U$ test. Result: There was a significant difference with $p$ value $=0.000$ between control and treatment group. Conclusion: Ginger extract can reduce the number of neutrophils cell in incision wound of white rats.
\end{abstract}

Keywords : Ginger (Zingiber Officinale Roscoe) Extract, Neutrophil Cell, Incision Wound

\section{INTRODUCTION}

Wounds is a discontinuities of tissue (Masir, 2012). Incision wounds is a wound that made by clean pieces use sharp tools (Smeltzer and Bare, 2002). Wound healing proccess through three phases, inflamation, proliferation, and maturation (Douglas, 2003).

To accelerate wound healing, proper wound care is required along with the use of antibiotics. Medicinal plants today are increasingly in demand as an alternative therapy that is not less important than medical therapy and have mild side effects.

One of medicinal plants that exist in Indonesia is ginger (Zingiber officinale roscoe). Ginger has an active substance that is oleoresin, gingerol, shogaol and flavonoids. Gingerol and shogaol are phenolic components of ginger that are known to have anti-inflammatory effects, anti-cancer, and antitumor (Wresdiyati, 2003; Rieska, 2004; Rizky, 2004; Sabina et al., 2010; Abdullah et al., 2010). Despite having many active substances that are beneficial to the body, the effects of ginger extract on neutrophil cells (which is a sign of the inflammatory phase) at the incision has not been studied. 


\section{METHOD}

This type of research is eksperimental research laboratory, with the design of the study is a post-test only control group design (Zainuddin, 2011). Samples are wistar strain white rats (Rattus norvegicus) with the male sex. Samples were taken by simple random sampling with sample number 30 .

The white rats were randomly selected and then divided into control groups (KK1, $\mathrm{KK} 5$, KK10) and treatment groups (KP1, KP5,KP10). The control group is a group of rats who were given orally solvent CMC $1 \%$. The incision is made along the $1 \mathrm{~cm}$ on the backs of mouse. The extract was given orally in the treatment group, once daily with a dose of $1 \mathrm{~g} / \mathrm{Kg}$ BW. Data collection was done by looking at histology preparation of skin tissue of white mouse under light microscope. Wounds were evaluated from day 1, 5, and 10.

Data analysis using descriptive analysis and inferential analysis. Inferential analysis includes normality analysis with Saphiro wilk test and homogeneity analysis with Levene Test test. Data distribution is not normal and is not homogeneous so that the Kruskal-Wallis test followed by a Mann-Whitney $U$ test with a significance level of $p<0.05$.

\section{RESULT AND DISCUSSION}

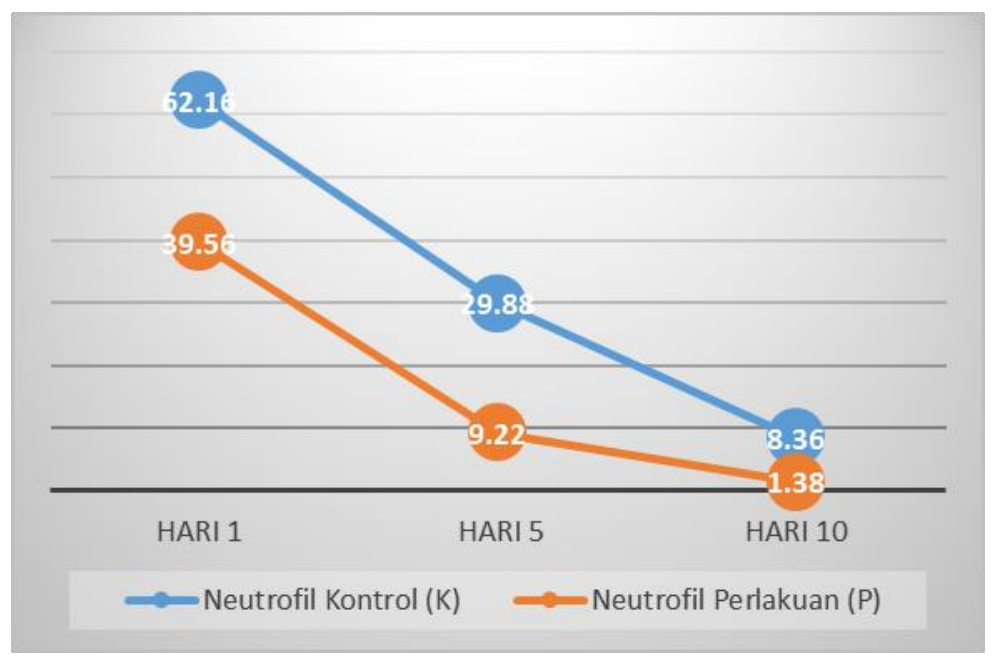

Figure 1 Graphs the mean neutrophil cells of control and treatment groups

Table 1 The result of Kruskall-Wallis test

\begin{tabular}{llll}
\hline Variable & $\mathrm{N}$ & $\mathrm{df}$ & $\mathrm{p}$ \\
\hline neutrophil cells & 30 & 5 & $0,000 *$
\end{tabular}

- Significant

Table 2 The result of Mann-Whitney test

\begin{tabular}{|c|c|c|c|}
\hline Variable & \multicolumn{2}{|c|}{ Group } & $\mathrm{p}$ \\
\hline \multirow[t]{2}{*}{ Neutrofil } & KK1 & KP1 & 0,175 \\
\hline & $\begin{array}{l}\text { KK2 } \\
\text { KK3 }\end{array}$ & $\begin{array}{l}\text { KP2 } \\
\text { KP3 }\end{array}$ & $\begin{array}{l}0,047 * \\
0,009 *\end{array}$ \\
\hline
\end{tabular}

- $\quad$ Significant 
Figure 1 shows that neutrophil cells was high in both groups at the beginning of the healing (day 1). In both groups have the same tendency that there is a drastic decline in the days that followed. The control group had a higher number of neutrophil cells than the treatment group on day one, but the difference in the two groups was not significant $(\mathrm{p}=$ $0,175 ; \alpha=0,05)$. Then on the fifth and tenth day, both groups experienced a decrease in neutrophil cell count, the neutrophil cell counts less in the treatment group. This is in accordance with the wound healing theory.

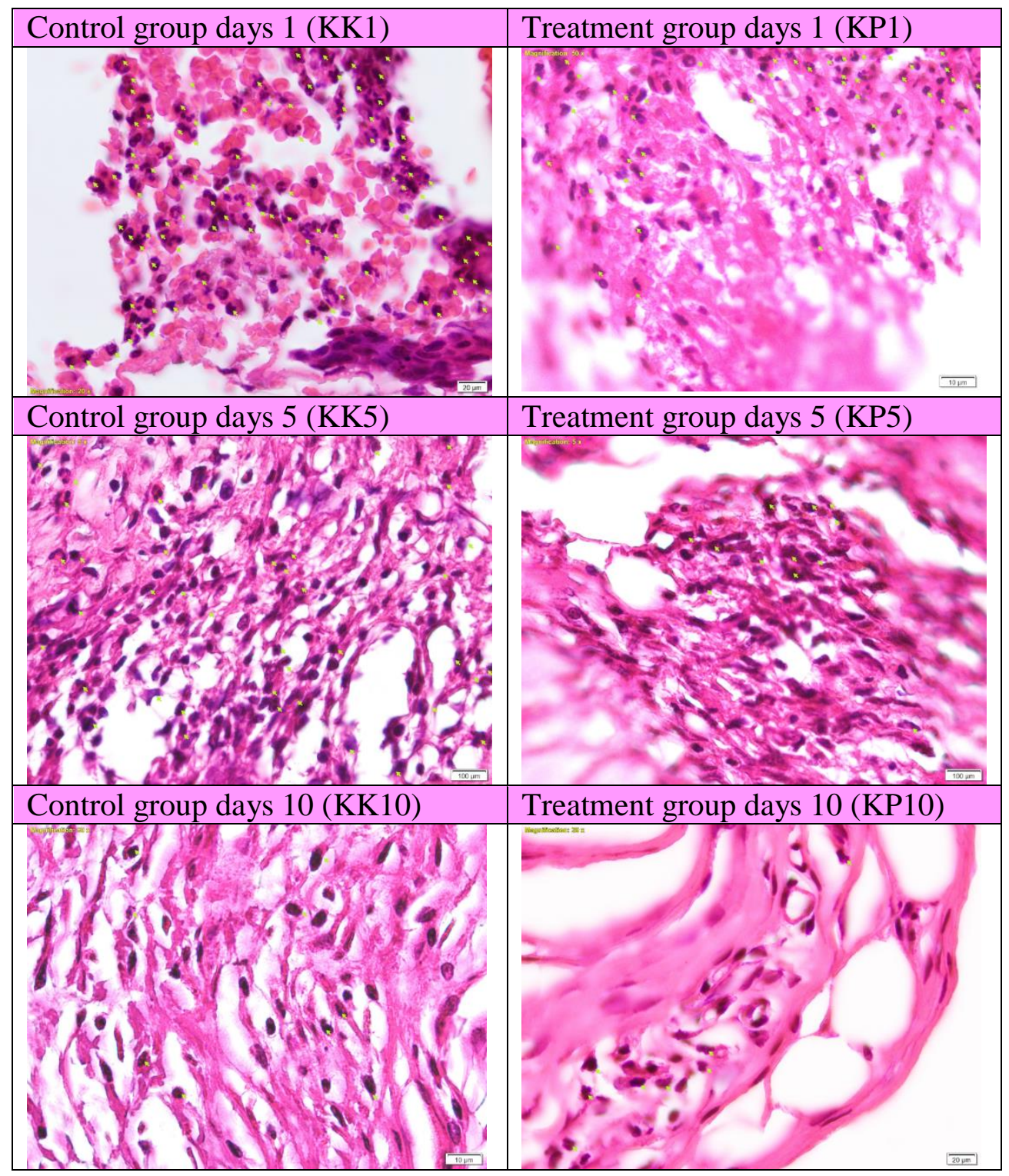

Figure 2 Microscopic picture of neutrophil cells in wound tissue

Based on Figure 2 can be seen that the number of neutrophil cells gradually become slightly from day to day. Within the first few hours after the inflammation begins, a large number of neutrophils from the blood begin to invade the inflamed area (Guyton, 2012). Neutrophil cell count will increase during the inflammatory phase that lasts up to 3-6 days and will decrease with the passage of wound healing process (Morison, 2004). 
Based on the Kruskal-Wallis test results showed that there were significant differences $(\alpha<0.05)$ in neutrophil cell variables with $p=0.000$ between treatment groups with the control. Furthermore, in the Mann-Whitney test results between the control group 5 (KK5) with treatment 5 (KP5), and the control group 10 (KK10) with treatment 10 (KP10), all three showed that there were significant differences in the number of neutrophil cells.

When an incision occurs, there will be an injury to the cell membrane. Injury to the cell membrane will trigger the arachidonic acid metabolism. Arachidonic acid undergoes metabolism in the cyclooxygenase pathway thus releasing inflammatory mediators, ie prostaglandins. Prostaglandins will cause vasodilation of blood vessels.

Ginger has an active substance that is oleoresin, gingerol, shogaol and flavonoids. Gingerol and shogaol are phenolic components of ginger that are known to have antiinflammatory effects, anti-cancer, and antitumor (Wresdiyati, 2003; Rieska, 2004; Rizky, 2004; Sabina et al., 2010; Abdullah et al., 2010). This active substance will inhibit cyclogsigenase activity so that the amount of prostaglandin as mediator of inflammation will decrease. This decrease in inflammatory mediators decreases the number of neutrophil cells.

Inflammatory processes persist within $24-48$ hours after injury, monocytes replacing neutrophils and becoming major leukocytes. Monocytes undergo phenotypic changes into tissue macrophages. Macrophages are the main cells and are important for wound repair. Within 1-2 days after injury, the remaining neutrophils are phagocytosed by macrophages so that the number of neutrophil cells decreases. The first phase of wound healing is over, while the proliferation and networking phases have been and are ongoing (Falanga, 2003).

\section{CONCLUSION}

Extracts of ginger (Zingiber officinale Roscoe) can decrease the number of neutrophil cells in the proliferative phase and maturation phase in rats (Rattus norvegicus) with the incision.

\section{ACKNOWLEDGEMENT}

The authors grateful to the ministry of research and technology of higher education, rector of Kadiri University, Directur of LP3M, Dean of Faculty of Health Science and colleagues.

\section{REFERENCES}

Abdullah, S., Abidin, S.A.Z., Murad, N.A., Makpol, S., Ngah, W.Z.W., \& Yusof, Y.A.M. (2010). Ginger extract (zingiber officinale) triggers apoptosis and $\mathrm{G}_{0} / \mathrm{G}_{1}$ cells arrest in HCT 116 and HT 29 colon cancer cell lines. African Journal of Biochemistry Research, 4(4), 134-142.

Falanga, V. (2003). Mechanisms of cutaneous wound repair. In: Freedberg IM, Wolff K, Eisen AZ, et al, editor. Fizpatrick's dermatology in general medicine (6th ed). New York: Graw-Hills.

Guyton. (2012). Textbook of medical physiology. Jakarta : EGC

Masir, O. (2012). Effect of cultur filtrate fibroblast fluid (cff) on wound healing; experimental research on rattus norvegicus galur wistar. Retrieved from http://jurnal.fk.unand.ac.id. 
Morison, M. J. (2004). Wound management. Jakarta : EGC

Rieska, A. (2004). Review of antioxidant and anticancer activity on drinking ginger juice (zingiber officinale var. amarum) pateurization. Essay FATETA. IPB Bogor

Rizki, Z.M. (2004). Study of antioxidant and anticancer activity on beverage formulation of ginger milk (zingiber officinale var. amarum) pateurization. Essay. FATETA. IPB Bogor

Sabina, E.P., Rasool, M.K., Mathew, L., Ezil, R.P., \& Indu, H. (2010). 6-Shogaol inhibit monosodium urate crystal-induced inflammation - an in vivo and in vitro study. $J$. Food and Chemical Technology 48, 229-235.

Smeltzer and Bare. (2002). Medical surgical nursing (p.119-120). Jakarta: EGC.

Wresdiyati, T., Astawan, M., Adnyane, I.K.M. (2003). Anti-inflammatory activity of oleoresin ginger (zingiber officinale) in rat kidney experiencing stress treatment. Jurnal Teknol. \& Industri Pangn, 14(2).

Zainuddin, M. (2011). Methodology of pharmaceutical and health research. Surabaya: Airlangga university press. 